\title{
Hubungan Paparan Kebisingan terhadap Peningkatan Tekanan Darah pada Pekerja
}

\author{
Leli Hesti Indriyanti ${ }^{1}$, Puspita Kurnia Wangi ${ }^{2}$, Kristina Simanjuntak ${ }^{3}$ \\ ${ }^{1}$ Program Studi Pendidikan Dokter Fakultas Kedokteran Universitas Muhammadiyah Prof. Dr. Hamka Jakarta \\ J1. Delima II/IV, Klender, RT.9/RW.3, Malaka Sari, Duren Sawit, Kota Jakarta Timur, Daerah Khusus Ibukota \\ Jakarta 13460 \\ ${ }^{2,3}$ Program Studi Pendidikan Dokter Fakultas Kedokteran Universitas Pembangunan Nasional Veteran Jakarta \\ Jl. RS Fatmawati, Pd. Labu, Cilandak, Kota Jakarta Selatan, Daerah Khusus Ibukota Jakarta 12450 \\ lelihesti_indriyati@uhamka.ac.id
}

\begin{abstract}
ABSTRAK
Prevalensi hipertensi di Jakarta pada usia lebih dari 18 tahun mencapai $46.25 \%$ pada wanita dan $41.97 \%$ pada pria, sedangkan $63.2 \%$ kasus hipertensi di masyarakat tidak terdiagnosis. Berbagai faktor risiko hipertensi ditemukan di banyak tempat termasuk di lingkungan kerja. Kebisingan adalah salah satu bahaya fisik yang dapat mempengaruhi tekanan darah dan merupakan faktor risiko untuk hipertensi. Penelitian ini dilakukan untuk mengidentifikasi hubungan antara kebisingan dan beberapa faktor di tempat kerja dengan prevalensi hipertensi. Studi cross-sectional dilakukan untuk mengetahui hubungan antara tingkat paparan kebisingan, masa kerja, penggunaan APD, dan karakteristik individu dan hipertensi. Sampel 104 pekerja diambil dari para pekerja di PT X. Data dikumpulkan melalui pemeriksaan fisik dan kuesioner. Analisis bivariat menggunakan uji Chi-Square menunjukkan bahwa intensitas kebisingan $(\mathrm{p}=0.001)$, BMI $(\mathrm{p}=0.001)$ dan kebiasaan merokok $(\mathrm{p}=0.006)$ adalah determinan independen untuk peningkatan tekanan darah. Responden yang terpapar bising lebih dari $\geq 85 \mathrm{~dB}$ memiliki 19.8 risiko hipertensi lebih besar dibandingkan dengan mereka yang terpapar kebisingan $<85 \mathrm{~dB}$. Ada pola respon-paparan yang signifikan $(\mathrm{P}=0.001)$ antara risiko hipertensi dan intensitas paparan kebisingan. Studi ini menunjukkan bahwa paparan kebisingan di tempat kerja dapat meningkatkan risiko terhadap terjadinya peningkatan tekanan darah.
\end{abstract}

Kata kunci: Kebisingan, Masa Kerja, APD, Tekanan Darah, Hipertensi

\begin{abstract}
Prevalence of hypertension In Jakarta on age over 18 years reach $46.25 \%$ at female and $41.97 \%$ at male, while $63.2 \%$ cases of hypertension in the community is not diagnosed. Various risk factors of hypertension are found in everywhere including in the work environment. Noise is one of the physical hazards that could affect blood pressure and is a risk factor for hypertension. Therefore, this study was conducted to identify an association between noise and some factors in workplace with the prevalence of hypertension. A cross-sectional study was carried out to find out the association between noise exposure level, working period, use of PPE, and individual characteristics and hypertension. A sample of 104 workers was taken from the workers in PT X. The data was collected through physical examination and questionnaires. Bivariate analysis using Chi-Square test showed that there were significant differences between noise intensity, BMI, and smoking in workers with increased blood pressure and workers with no increased blood pressure $(\mathrm{p}<0.05)$. In the multivariate analysis, noise intensity $(\mathrm{p}=0.001), \mathrm{BMI}(\mathrm{p}=0.001)$ and smoking $(\mathrm{p}=0.006)$ were independent predictors for the incease of blood pressure. The study showed that the prevalence of hypertension is associated with the occupational noise exposure and highly influenced by BMI group overweight and smoking after our final regression analysis. This association may translate into a higher incidence of hypertension.
\end{abstract}




\section{Pendahuluan}

Tingkat kebisingan kerja yang tinggi masih menjadi masalah di semua wilayah di dunia. Di Amerika Serikat (AS), misalnya, lebih dari 30 juta pekerja terkena kebisingan berbahaya. Di Jerman, 4-5 juta orang (12-15\% dari angkatan kerja) terpapar pada tingkat kebisingan yang didefinisikan sebagai berbahaya oleh WHO. Tingkat paparan kebisingan kerja yang tinggi menimbulkan risiko yang signifikan terhadap kesehatan dan keselamatan kerja. Sebuah survei nasional Inggris menemukan bahwa paparan kebisingan di lingkungan kerja bertanggung jawab atas kesulitan pendengaran yang parah pada sekitar 153.000 pria dan 26.000 wanita, berusia 35 sampai 64 tahun dengan tinitus persisten yang jauh lebih banyak (266.000 pria, 84.000 wanita). Di AS, gangguan pendengaran yang disebabkan oleh kebisingan atau Noise Induced Hearing Loss (NIHL) menyumbang sekitar $11 \%$ dari semua penyakit akibat kerja ${ }^{1}$.

Selain mempengaruhi pendengaran, kebisingan juga dikaitkan dengan peningkatan risiko penyakit kardiovaskular yakni infark miokard, stroke, dan hipertensi. Hipertensi merupakan salah satu penyakit pembuluh darah, dikenal sebagai silent killer. Penyakit ini sering tidak menimbulkan gejala hingga berkembang mejadi penyakit yang lebih serius $^{2}$. Hipertensi merupakan penyebab kematian dari 9.4 juta jiwa setiap tahun ${ }^{3}$. Patofisiologi kebisingan untuk menginduksi hipertensi dihipotesiskan sebagai keterlibatan mekanisme stres disfungsional. Sistem pendengaran yang juga terkait dengan sistem saraf simpatik dan sistem neuroendokrin bereaksi terhadap stimulus suara melalui refleks yang dibuktikan oleh efek kardiovaskular seperti perubahan katekolamin, epinefrin dan non-epinefrin, serta tingkat kortikosteroid. Paparan terus menerus dan pengulangan terhadap kebisingan dapat bersifat patogenik, yang mengarah pada naiknya regulasi otomatis vaskular yang terus-menerus sehingga menyebabkan hipertensi ${ }^{4}$.

Sebuah penelitian yang dilakukan oleh Li Y, Chen G, Yu S, dimana di antara 3150 pekerja di sebuah pabrik baja di Zhengzhou, China menunjukkan prevalensi hipertensi pada $29,88 \%$ laki-laki dan $12,13 \%$ perempuan yang terpapar dengan tingkat paparan kebisingan kumulatif $95 \mathrm{~dB}$ hingga $113 \mathrm{~dB}{ }^{5}$. Penelitian yang dilakukan oleh Hastuti pada tahun 2004, menyatakan bahwa sebanyak $26,7 \%$ pekerja yang terpapar kebisingan kurang atau sama dengan 85 dBA mengalami peningkatan tekanan sistolik dan sebanyak 33\% pekerja mengalami peningkatan tekanan darah diastolik $^{6}$. Sedangkan dalam penelitian yang dilakukan Rosidah pada Tahun 2004, menyatakan bahwa kejadian hipertensi lebih banyak terjadi pada kelompok responden yang tinggal di daerah dengan intensitas bising lebih dari nilai ambang batas dengan prevalensi $54.4 \%$ dan pada kelompok daerah dengan kebisingan kurang dari nilai ambang dengan prevalensi sebesar $50 \%{ }^{7}$.

PT. X merupakan perusahaan yang bergerak di bidang pemeliharaan transportasi darat (kereta api) dan pembuatan suku cadang. 
Leli Hesti Indriyanti, Puspita Kurnia Wangi, Kristina Simanjuntak. Hubungan Paparan Kebisingan terhadap Peningkatan Tekanan Darah pada Pekerja.

DOI :

Perusahaan ini terbentuk pada tahun 1920. Perusahaan ini mempunyai bengkel besar, memiliki sumber daya manusia sebanyak 387 orang dengan masa kerja yang bervariasi. Dalam lingkungan kerjanya, para pekerja ini sehari-hari terpapar oleh kebisingan yang saat pengukuran dengan sound level meter di beberapa titik pengukuran mencapai hingga $100 \mathrm{~dB}$. Hal ini tentu saja harus mendapatkan perhatian karena dapat menyebabkan gangguan kesehatan termasuk peningkatan tekanan darah.

Studi ini dilakukan untuk mengetahui hubungan antara paparan kebisingan terhadap peningkatan tekanan darah pada pekerja di PT X tahun 2017.

\section{Metode}

Jenis penelitian yang dilakukan adalah obsevasional analitik dengan pendekatan cross sectional. Penelitian dilakukan di PT X, Jakarta pada bulan Februari-Maret tahun 2017 dengan populasi penelitian adalah seluruh pekerja di PT X. Sampel terdiri dari 104 pekerja yang diambil dari database perusahaan yakni pekerja di bengkel $\mathrm{X}$ yang berasal dari departemen yang berbeda-beda dan telah memenuhi kriteria inklusi dan eksklusi. Kriteria inklusi untuk populasi penelitian adalah pekerja laki-laki yang bersedia mengikuti penelitian. Sedangkan kriteria eksklusi adalah pekerja yang memiliki riwayat hipertensi, memiliki gangguan pendengaran serta sedang mengkonsumsi obatobatan yang mempengaruhi tekanan darah. Pekerja yang memiliki penyakit ginjal, kardiovaskular, diabetes mellitus dan penyakit kronik lainnya yang dapat mempengaruhi tekanan darah juga masuk dalam kriteria eksklusi.

Kuesioner kepada para peserta penelitian dikembangkan melalui wawancara untuk mendapatkan beberapa informasi umum peserta. Meliputi data demografi dan riwayat profesional (masa bekerja di perusahaan, lamanya paparan harian untuk kebisingan, dan penggunaan Alat pelindung diri atau APD), riwayat medis masa lalu dan sekarang (riwayat hipertensi, riwayat penyakit lainnya) yang dapat mempengaruhi tekanan darah serta riwayat adanya gangguan pendengaran. Kebiasaan merokok ditanyakan meliputi jumlah atau frekuensi merokok per hari selama 1 tahun terakhir. Semua subjek mengisi kuesioner setelah memberikan informed consent dan sebelum pemeriksaan fisik.

Para pekerja yang terpilih kemudian dilakukan pengukuran berat badan dengan menggunakan timbangan dan tinggi badan dengan menggunakan microtoise, untuk kemudian dilakukan penghitungan IMT (Indeks Massa Tubuh). Pengukuran tekanan darah dengan menggunakan sphygmomanometer. Pengukuran ini dilakukan sebelum bekerja dan setelah selesai bekerja. Penilaian paparan kebisingan dan dinilai selama 8 jam kerja. Alat pengukur kebisingan portabel yakni soundlevel meter digunakan untuk menentukan intensitas kebisingan selama jam kerja mereka. Tingkat paparan kebisingan di pabrik kemudian diklasifikasikan ke dalam 2 kategori yakni $<85$ $\mathrm{dB}$ dan lebih dari $85 \mathrm{~dB}$.

Untuk melihat karakteritik dari seluruh responden, tabulasi frekuensi digunakan. Di samping itu, untuk mengukur hubungan antara variabel independen dengan dependen 
dilakukan uji uji Chi-square, dan bila tidak memenuhi syarat maka dilakukan uji alternatif lain diantaranya uji gabung sel. Setelah dilakukan uji univariat dan bivariat untuk mengetahui faktor risiko yang paling berpengaruh dalam meningkatnya tekanan darah dilakukan uji multivariat dengan menggunakan uji regresi logistik. Tujuan studi ini adalah untuk melihat hubungan antara paparan kebisingan di tempat kerja dengan risiko terjadinya peningkatan tekanan darah pada pekerja di PT X.

\section{Hasil}

Subjek yang mengikuti studi sebanyak 104 responden, diketahui bahwa responden yang berusia $<40$ tahun sebanyak 55 orang $(52.9 \%)$, dan usia $\geq 40$ tahun sebanyak 49 orang $(47.1 \%)$. Responden dengan IMT normal sebanyak 54 orang (51.9\%), dan obese sebanyak 50 orang $(48.1 \%)$, serta responden yang memiliki kebiasaan merokok sebanyak 63 orang $(60.6 \%)$ seperti yang terlihat pada tabel 1 .

Tabel 1. Distribusi Frekuensi Karakteristik Individu

\begin{tabular}{|c|c|c|}
\hline $\begin{array}{c}\text { Karakteristik } \\
\text { Individu } \\
\end{array}$ & Frekuensi & $\begin{array}{c}\text { Persentase } \\
(\%)\end{array}$ \\
\hline \multicolumn{3}{|l|}{ Usia } \\
\hline$<40$ tahun & 55 & 52.9 \\
\hline$\geq 40$ tahun & 49 & 47.1 \\
\hline \multicolumn{3}{|l|}{ Kebiasaan } \\
\hline Merokok & 63 & 60.6 \\
\hline Ya & 41 & 39.4 \\
\hline \multicolumn{3}{|l|}{ Tidak } \\
\hline \multicolumn{3}{|l|}{ Indeks Masa } \\
\hline Tubuh & 54 & 51.9 \\
\hline Normal & 50 & 48.1 \\
\hline Obese & & \\
\hline
\end{tabular}

Berdasarkan riwayat pekerjaan seperti yang terlihat pada tabel 2, responden yang memiliki masa kerja <10 tahun sebanyak 67 orang (64.4\%), $\geq 10$ tahun sebanyak 37 orang (35.6\%). Tabel 2 juga menunjukkan data bahwa sebanyak 70 responden (67.3\%) terpapar kebisingan di atas ambang batas yaitu $>85$ dBA dengan riwayat pekerja yang terpapar kebisingan dengan waktu $>8$ jam hanya sebanyak 15 orang (14.4\%). Namun demikian, dari semua yang terpapar kebisingan ditempat kerja sebanyak 89 orang $(85.6 \%)$ tidak menggunakan alat pelindung diri/alat pelindung telinga saat bekerja.

Tabel 2. Distribusi Frekuensi Riwayat Pekerjaan

\begin{tabular}{lcc}
\hline \multicolumn{1}{c}{ Variabel } & $\begin{array}{c}\text { Frekuens } \\
\text { i }\end{array}$ & $\begin{array}{c}\text { Persentase } \\
(\%)\end{array}$ \\
\hline $\begin{array}{l}\text { Masa Kerja } \\
<10 \text { tahun }\end{array}$ & 67 & 64.4 \\
$\geq 10$ tahun & 37 & 35.6 \\
& & \\
Intensitas Kebisingan & & \\
$\leq 85 \mathrm{dBA}$ & 34 & 32.7 \\
$>85 \mathrm{dBA}$ & 70 & 67.3 \\
& & \\
Paparan Kebisingan & & \\
$\leq 8$ jam & 89 & 85.6 \\
$>8$ jam & 15 & 14.4 \\
Penggunaan APD & & \\
Ya & 89 & 85.6 \\
Tidak & 15 & 14.4 \\
\hline
\end{tabular}

Tabel 3 menunjukkan bahwa dari semua responden yang diteliti, diketahui bahwa sebanyak 64 responden $(61.5 \%)$ mengalami peningkatan tekanan darah, sedangkan yang tidak mengalami peningkatan adalah $38.5 \%$ atau sebanyak 40 responden.

Tabel 3. Distribusi Frekuensi Peningkatan Tekanan Darah

\begin{tabular}{ccc}
\hline $\begin{array}{c}\text { Peningkatan } \\
\text { Tekanan Darah }\end{array}$ & Frekuensi & Persentase (\%) \\
\hline Ya & 64 & 61.5 \\
Tidak & 40 & 38.5 \\
\hline
\end{tabular}


Leli Hesti Indriyanti, Puspita Kurnia Wangi, Kristina Simanjuntak. Hubungan Paparan Kebisingan terhadap Peningkatan Tekanan Darah pada Pekerja.

DOI :

Setelah mengukur hubungan bivariat dari karakteristik individu, terlihat dari tabel 4 ,bahwa variable yang mempunyai pengaruh terhadap peningkatan tekanan darah adalah indeks masa tubuh (IMT) dimana hasil uji chi square menunjukkan $\mathrm{p}=0.006$ dan kebiasaan merokok $(\mathrm{p}=0.017)$. Sementara itu, usia ternyata tidak berpengaruh terhadap peningkatan tekanan darah pada pekerja yang diteliti $(\mathrm{p}=0.384)$.

Tabel 4. Hubungan Karaktersitik Individu dengan Peningkatan Tekanan Darah

\begin{tabular}{|c|c|c|c|c|c|c|c|}
\hline \multirow{3}{*}{ Variabel } & \multicolumn{4}{|c|}{ Peningkatan Tekanan Darah } & \multirow{2}{*}{\multicolumn{2}{|c|}{ Total }} & \multirow{3}{*}{ P Value } \\
\hline & \multicolumn{2}{|c|}{ Ya } & \multicolumn{2}{|c|}{ Tidak } & & & \\
\hline & $\mathbf{n}$ & $\%$ & $\mathbf{n}$ & $\%$ & $\mathbf{N}$ & $\%$ & \\
\hline \multicolumn{8}{|l|}{ Usia } \\
\hline$\leq 40$ Tahun & 36 & 65.5 & 19 & 34.5 & 55 & 100 & 0.384 \\
\hline > Tahun & 28 & 30.2 & 21 & 18.8 & 49 & 100 & \\
\hline \multicolumn{8}{|c|}{ Indeks Massa Tubuh } \\
\hline Normal & 40 & 74.1 & 14 & 25.9 & 54 & 100 & 0.006 \\
\hline obese & 24 & 48 & 26 & 52 & 50 & 100 & \\
\hline \multicolumn{8}{|c|}{ Kebiasaan Merokok } \\
\hline Ya & 33 & 52.4 & 30 & 24.2 & 63 & 100 & 0.017 \\
\hline Tidak & 31 & 75.6 & 10 & 24.4 & 41 & 100 & \\
\hline
\end{tabular}

Pada tabel 5 menunjukkan bahwa dari riwayat pekerjaan, hanya intensitas kebisingan merupakan variable yang paling berpengaruh $(\mathrm{p}=0.001)$, sedangkan masa kerja $(\mathrm{p}=0.174)$, lama paparan kebisingan $(\mathrm{p}=0.659)$, dan penggunaan APD $\quad(\mathrm{p}=0.310)$ tidak menunjukkan pengaruhnya terhadap peningkatan tekanan darah.

Tabel 5. Hubungan Riwayat Pekerjaan dengan Peningkatan Tekanan Darah

\begin{tabular}{|c|c|c|c|c|c|c|c|}
\hline \multirow{3}{*}{ Variabel } & \multicolumn{4}{|c|}{ Peningkatan Tekanan Darah } & \multirow{2}{*}{\multicolumn{2}{|c|}{ Total }} & \multirow{3}{*}{ P Value } \\
\hline & \multicolumn{2}{|c|}{ Ya } & \multicolumn{2}{|c|}{ Tidak } & & & \\
\hline & $\mathbf{n}$ & $\%$ & $\mathbf{n}$ & $\%$ & $\mathbf{N}$ & $\%$ & \\
\hline \multicolumn{8}{|l|}{ Masa Kerja } \\
\hline$<$ Tahun & 38 & 56.7 & 29 & 43.3 & 67 & 100 & 0.174 \\
\hline$\geq 10$ Tahun & 26 & 70.3 & 11 & 29.7 & 37 & 100 & \\
\hline \multicolumn{8}{|c|}{ Intensitas Kebisingan } \\
\hline$<85 \mathrm{~dB}$ & 54 & 77.1 & 16 & 22.9 & 70 & 100 & 0.001 \\
\hline$\geq 85 \mathrm{~dB}$ & 10 & 29.4 & 24 & 70.6 & 34 & 100 & \\
\hline \multicolumn{8}{|c|}{ Lama Paparan Bising } \\
\hline$>8 \mathrm{Jam}$ & 10 & 66.7 & 5 & 33.3 & 15 & 100 & 0.659 \\
\hline$\leq 8 \mathrm{Jam}$ & 54 & 60.7 & 35 & 39.3 & 89 & 100 & \\
\hline \multicolumn{8}{|l|}{$\overline{\text { Penggunaan APD }}$} \\
\hline Tidak & 53 & 59.6 & 36 & 40.4 & 89 & 100 & 0.310 \\
\hline $\mathrm{Ya}$ & 11 & 73.3 & 4 & 26.7 & 15 & 100 & \\
\hline
\end{tabular}

Analisis multivariat bertujuan untuk mendapatkan seberapa besar faktor mempengaruhi terjadinya peningkatan tekanan darah. Dalam pemodelan ini semua variabel kandidat dicobakan secara bersama-sama. Berdasarkan analisis multivariat dengan menggunakan uji regresi logistik dan metode enter, didapatkan hasil akhir sebagai berikut. 
Tabel 6. Hasil Analisis Multivariat Model Akhir Faktor Risiko Peningkatan Tekanan Darah Pada Pekerja PT X

\begin{tabular}{lccc}
\hline \multicolumn{1}{c}{ Variabel } & Koefisien & Nilai p & OR \\
\hline Intensitas Bising & 2.991 & 0.001 & 19.897 \\
Lama Paparan Bising & 1.091 & 0.194 & 2.977 \\
Penggunaan APD & -1.600 & 0.081 & 0.202 \\
IMT & -2.169 & 0.001 & 0.114 \\
Kebisaan Merokok & -1.582 & 0.006 & 0.206 \\
\hline Konstanta & 1,964 & 0,060 & 7,127 \\
\hline
\end{tabular}

Berdasarkan analisis multivariat pada tabel diatas, variabel yang berhubungan secara bermakna dengan peningkatan tekanan darah adalah variabel intensitas bising, IMT, dan kebiasaan merokok. sedangkan variabel penggunaan APD dan lama paparan bising adalah sebagai variabel pengontrol (counfounding). Variabel yang paling dominan berhubungan dengan peningkatan tekanan darah adalah intensitas kebisingan. Hasil analisis didapatkan Odds Ratio (OR) dari variabel intensitas kebisingan adalah 19.8, artinya pekerja yang terpapar kebisingan di atas $\mathrm{NAB}(>85 \mathrm{~dB})$ akan mengalami peningkatan tekanan darah sebesar 20 kali lebih tinggi dibandingkan pekerja yang terpapar kebisingan namun nilainya masih dibawah NAB.

\section{Pembahasan}

Hasil penelitian menunjukkan bahwa variabel yang paling dominan berhubungan dengan peningkatan tekanan darah adalah intensitas kebisingan dengan risiko sebesar 19,8 kali untuk mengalami peningkatan tekanan darah. Hal ini sesuai dengan penelitian Attarchi dkk ${ }^{8}$, dan Kalantary yang menyatakan bahwa pekerja yang terpapar kebisingan mengalami peningkatan tekanan darah ${ }^{9}$.

Hal tersebut terjadi karena terdapat berbagai mekanisme bahwa kebisingan menyebabkan meningkatnya stress pada seseorang. Menurut Attarchi, dkk menyatakan bahwa stress menyebabkan peningkatan tekanan darah melalui aktivasi saraf simpatis ${ }^{8}$. Babicsh menyatakan bahwa paparan kebisingan yang akut dapat menyebabkan meningkatnya tekanan darah, detak jantung, dan curah jantung melalui pengeluaran hormon stress seperti katekolamin ${ }^{10}$. Hal ini didukung dengan penelitian Neghab dkk, bahwa terdapat peningkatan sekresi vasokontriktor pada urin seseorang yang terpapar kebisingan lebih dari $90 \mathrm{~dB}^{11}$. Beberapa penelitian menyatakan bahwa terdapat peningkatan yang signifikan ketika seseorang terpapar kebisingan. Saat seseorang mengalami stres maka corticotropin-releasing hormone $(\mathrm{CRH})$ dan arginine-vassopressine (AVP) akan disekresi oleh hipotalamus. CRH akan menstimulasi sekresi hormone kortikotropin. Akibatnya kortikotropin akan menstimulasi peningkatan produksi kortikosteroid termasuk kortisol. Sedangkan hormone vasopressin akan meningkatkan reabsorbsi air oleh ginjal dan menginduksi terjadinya vasokonstriksi sehingga menyebabkan peningkatan tekanan darah. Secara bersamaan CRH dan hormone vasopressin akan mengaktifkan hypothalamicpituitary-adrenal-axis (HPA axis). HPA axis 
Leli Hesti Indriyanti, Puspita Kurnia Wangi, Kristina Simanjuntak. Hubungan Paparan Kebisingan terhadap Peningkatan Tekanan Darah pada Pekerja.

DOI :

akan memberikan umpan balik antara hipotalamus, kelenjar pituitary, dan kelenjar adrenal menurut Randall ${ }^{12}$.

Menurut Spreng, paparan kebisingan dalam jangka panjang dapat menyebabkan hiporeaksi dan hiperreaksi, yang dapat mengindikasikan adanya kelainan regulasi pada $H P A$ axis $^{13}$. Selain itu penelitian yang dilakukan oleh Pickering, menyatakan bahwa stress akut maupun kronik dapat menyebabkan meningkatnya pelepasan sitokin, bukan hanya sebagai penanda, namun juga sebagai mediator inflamasi yang menyebabkan disfungsi endotel pembuluh darah dan proses aterosklerosis ${ }^{14}$. Sehingga pada akhirnya terjadi peningkatan tekanan darah yang secara kronik dapat menyebabkan hipertensi.

Sementara itu, hasil penelitian menunjukkan bahwa tidak terdapat hubungan antara masa kerja dengan peningkatan tekanan darah $(\mathrm{p}=0.174)$. Hal ini sesuai dengan penelitian Nugraha, mengenai hubungan kebisingan dan hipertensi.pada karyawan lakilaki di Plant 3-4 PT. I yang menyatakan bahwa tidak terdapat hubungan yang signifikan antara lama masa kerja dengan kejadian hipertensi ${ }^{15}$. Hal ini sejalan pula dengan penelitian yang dilakukan oleh Harianto dan Pratomo mengenai pajanan kebisingan dan hipertensi di kalangan pekerja pelabuhan menyatakan bahwa masa kerja tidak menunjukkan hubungan yang signifikan dengan kejadian hipertensi ${ }^{16}$. Sejalan dengan masa kerja, paparan bising juga tidak menunjukkan dengan peningkatan tekanan darah $(\mathrm{p}=0.659)$. Hal ini sesuai dengan penelitian Anggraini yang menyatakan bahwa tidak ada hubungan yang signifikan antara lama pemaparan bising per hari dengan risiko hipertensi ${ }^{17}$. Namun hal ini bertentangan dengan hasil penelitian Zulharmans, yang menyatakan bahwa terdapat hubungan antara lama paparan bising dan tekanan darah ${ }^{18}$. Hal tersebut didukung oleh penelitian Filaely, yang menyatakan bahwa terdapat hubungan yang signifikan antara lama pajanan bising dengan meningkatnya tekanan darah pada pegawai di Stasiun Besar Semarang Poncol ${ }^{19}$. Menurut Zulharmans emakin lama seseorang terpapar kebisingan maka akan menyebabkan meningkatnya hormon stress yang menyebabkan peningkatan denyut jantung sehingga meningkatkan curah jantung dan tekanan darah ${ }^{18}$.

Selain intensitas kebisingan, faktor lain yang berpengaruh terhadap peningkatan tekanan darah adalah indeks masa tubuh dengan $(\mathrm{p}=0.006)$. Hal ini sesuai dengan penelitian Mungreiphy dkk, yang menyatakan bahwa semakin meningkatknya IMT maka semakin meningkat pula tekanan darahnya .Hal tersebut terjadi karena pada seseorang yang mengalami obesitas terjadi peningkatan lemak pada lapisan visceral yang dapat menyebabkan hipertensi ${ }^{20}$. Hall dkk menyatakan bahwa, obesitas berhubungan dengan bertambahnya cairan ekstraseluler dan meningkatkan aliran darah pada jaringan sehingga meningkatkan aliran balik vena dan curah jantung ${ }^{21}$. Tingginya konsumsi lemak dan karbohidrat diketahui dapat menstimulasi reseptor $\alpha 1$ pada perifer dan $\beta$ adrenergik yang menyebabkan peningkatan aktivitas simpatis sehingga menyebabkan peningkatan tekanan darah.

Dari karakteristik individu, ternyata 
disisi lain, hasil penelitian menunjukkan bahwa tidak terdapat hubungan antara usia dengan peningkatan tekanan darah $(\mathrm{p}=0.384)$. Hal ini sejalan dengan penelitian yang dilakukan oleh Sorensen dkk, dengan menggunakan studi kohort mengenai efek paparan bising lalu lintas dan kereta api terhadap hipertensi yang dilakukan di Kopenhagen bahwa tidak ada hubungan yang signifikan antara usia dengan prevalensi hipertensi ${ }^{22}$. Hal ini bertentangan dengan penelitian yang dilakukan oleh Harianto dan Pratomo, bahwa didapatkan prevalensi hipertensi meningkat seiring dengan meningkatnya usia, pada kelompok usia 18-27 tahun sekitar $12.73 \%$, pada usia $28-42$ tahun meningkat menjadi $17.96 \%$, dan usia $>42$ tahun sebesar 41.67\%. Pada usia $>42$ menunjukkan hubungan yang bermakna dengan kejadian hipertensi $(\mathrm{p}=0.000)$ dengan $\mathrm{POR}=5.89^{16}$.

Faktor lain yang menunjukkan pengaruh terhadap peningkatan tekanan darah adalah kebiasaan merokok dengan $(\mathrm{p}=0.017)$. Hal ini sesuai dengan penelitian Primatesta, mengenai hubungan antara merokok dengan tekanan darah dari survey kesehatan di Inggris ${ }^{23}$, serta Anggara dan Prayitno, yang menyatakan bahwa terdapat hubungan yang bermakna antara kebiasaan merokok dengan tekanan darah ( $p=0.000)$. Hal tersebut terjadi karena kandungan dari rokok, seperti nikotin, dapat mengaktifkan radikal bebas ${ }^{24}$. Menurut Ambrose, Terjadinya disfungsi vasomotor yang diinduksi oleh nitrit oksida, inflamasi, dan modifikasi komponen lipid, sehingga terjadi pembentukan aterosklerosis yang berdampak pada perubahan tekanan darah dan menjadi faktor risiko hipertensi ${ }^{25}$. Penelitian yang dilakukan oleh Smith, menunjukkan bahwa merokok dapat meningkatkan 20-25\% kadar leukosit perifer serta meningktakan aktivasi mediator inflamasi sperti interleuikin6 (IL-6), protein C-reaktif, dan tumor necrosis factor $\alpha \quad($ TNF $\alpha)$. Peningkatan sitokin proinflamasi menyebabkan terjadinya peningkatan interaksi leukosit- endotel yang merupakan peristiwa awal terjadinya aterosklerosis ${ }^{26}$.

Dalam hal penggunaan APD, ternyata juga tidak menunjukkan hasil yang signifikan. Hal ini sejalan dengan penelitian yang dilakukan oleh Saryawati, menegenai faktor risiko kejadian hipertensi pada pekerja industri tekstil yang menunjukkan tidak terdapat hubungan penggunaan APD dengan kejadian hipertensi ${ }^{27}$. Namun hal ini bertentangan dengan penelitian yang dilakukan oleh Hidayat, yang menyatakan bahwa terdapat hubungan antara perubahan tekanan darah dengan penggunaan earplug $(\mathrm{p}=0.001)^{28}$. Penelitian yang dilakukan oleh Buchari, menyatakan bahwa APD yang digunakan untuk melindungi seseorang dari bahaya kebisingan dengan intensitas tinggi adalah jenis earplug dan earmuff. Sumbat telinga (earplug) dapat mengurangi kebisingan 8-30 $\mathrm{dB}$ dan biasanya digunakan untuk proteksi hingga $100 \mathrm{~dB}$. Tutup telinga (earmuff) dapat menurunkan kebisingan 25-40 dB dan biasanya digunakan untuk proteksi hingga 110 $\mathrm{dB}^{29}$.

Penelitian yang dilakukan oleh Zauzan dalam Setyaningrum dkk, menyatakan bahwa sebelum penggunaan APD dilakukan, terdapat 
Leli Hesti Indriyanti, Puspita Kurnia Wangi, Kristina Simanjuntak. Hubungan Paparan Kebisingan terhadap Peningkatan Tekanan Darah pada Pekerja.

DOI :

beberapa cara pengedalian kebisingan yaitu eliminasi, substitusi, isolasi, engineering, administratif, dan penggunaan alat pelindung diri. Eliminasi yaitu dengan cara menghilangkan bahan atau proses kerja yang berbahaya, substitusi dengan cara mengganti bahan atau proses dengan yang lebih aman, isolasi dengan cara memisahkan pekerja dengan sumber bahaya, engineering dengan cara membuat atau merekayasa mesin yang membahayakan pekerja seperti memberikan pelindung pada mesin, administratif dengan cara job rotation, dan yang terakhir ialah pemberian alat pelindung diri untuk pekerja ${ }^{30}$. Kurangnya kedisiplinan pekerja dalam penggunaan APD dapat disebabkan oleh ketidaknyamanan dalam penggunaan APD, ataupun terganggunya komunikasi antar pekerja. Oleh karena itu, dapat diterapkan kebijakan wajib menggunakan APD serta pemantauan dalam penggunaannya.

\section{Kesimpulan}

Studi ini menyimpulkan bahwa adanya intensitas kebisingan yang sudah melebihi nilai ambang batas $(85 \mathrm{dbB})$ ternyata dapat memperbesar risiko terjadinya peningkatan tekanan darah para pekerja yang berujung pada kejadian hipertensi di tempat kerja. Oleh karena itu penting untuk merencanakan berbagai upaya pencegahan untuk mengurangi kebisingan di lingkungan kerja agar angka kejadian hipertensi diantara para pekerja tidak meningkat.

\section{Daftar Pustaka}

1. Feder K dkk. Prevalence of Hazardous Occupational Noise Exposure, Hearing Loss, and Hearing Protection Usage Among a Representative Sample of Working Canadians. J Occup Environ Med. 59.

2. Siyad AR. Hypertention. Hygeia J Drugs Med. 2011;Vol.3.

3. Organization WH. A Global Global Brief on Hypertension, Geneva World Health Organization. 2013.

4. Ankita, S \& Mai S. Occupational Noise Exposure in Relation to Hypertension: A Cross-sectional Study in the Steel Factory. Occupattional Med Heal Aff. 2017;5:(3).

5. Li Y, Chen G YS. Prevalence and Influence Factors of Hypertension A mong The Workers Exposed to Noise in Steel Making and Steel Rolling Workshop of An Iron and Steel Plant. Artic Chinese. 2015;May;49(5):

6. Hastuti E. Pengaruh Bising terhadap Kenaikan Tekanan Darah pada Pekerja di Bandara Ahmad Yani Semarang. Universitas Diponegoro Semarang; 2004.

7. Rosidah R. Studi Kejadian Hipertensi Akibat Bising pada Wanita yang Tinggal di Sekitar Lintasan Kereta Api. Universitas Diponegoro Semarang; 2004.

8. Attarchi M dkk. Effect of Exposure to Occupational Noise and Shift Workin on Blood Pressure in Rubber Manufacturing Company Workers. Ind Health. 2012; Vol. 50.

9. Kalantary $S$ dkk. The Effects of Occupational Noise on Blood Pressure and Heart Rate of Workers in an Automotive Parts Industry. ARYA Atheroscelorsis. 2015;Vol.11:215-9.

10. Babisch W. Cardiovascular Effects of Noise. Noise Heal. 2011; Vol.13.

11. Neghab M, Maddahi, M, Rajaeefard A. Hearing Imparment and Hypertension Associated with Long Term Occupational Exposure to Noise. Iran Red Crescent Med J. 2009; Vol.11.

12. Randall M. The Physiology of Stress: Cortisol and the Hypothalamic PituitaryAdrenal Axis. 2011;

13. Spreng M. Possible Health Effects of Noise Induced Cortisol Increase. Noise Heal. 2000; Vol.2.

14. Pickering T. Stress, Inflamation, and 
Hypertension. J Clin Hypertens. 2007; Vol.9.

15. Nugraha S. Kebisingan dan Hipertensi pada Karyawan Laki-Laki di Plant 3-4 PT. "I." Universitas Indonesia; 2005.

16. Harianto, E \& Pratomo H. Pajanan Kebisingan dan Hipertensi di kalangan Pekerja Pelabuhan. J Kesehat Masy Nas. 2013;Vol.8, No.:5.

17. Anggraeni V. Tingkat Kebisingan Lalu Lintas dan Risiko Hipertensi pada Supir Angkutan Umum KWK Wilayah Jakarta Timur Tahun 2012. Universitas Indonesia; 2012.

18. Zulramhans, Russeng, S, Wahyuni A. Hubungan Kebisingan dengan Tekanan Darah pada Karyawan Bagian Produksi PT. Semen Tonasa. Repos Unhas. 2014;

19. Prafista F. Faktor-Faktor yang Berhubungan dengan Kenaikan Tekanan Darah pada Pegawai yang Terpapar Kebisingan di Stasiun Besar Semarang Poncol. 2009.

20. Mungreuphy, NK, Kapoor, S, Sinha R. Association Between BMI, Blood Pressure and Age: Study Among Tangkhul Naga Tribal Males of Northeast India. J Anthropol. 2011;

21. Hall dkk. Obesity-Induced Hypertension: Interaction of Neurohormonal and Renal Mechanisms. Am Hear Assoc Journals. 2015; Vol.116.

22. Sorensen, M, Hyidberg, M, Hoffmann, B, Andersen ZJ, Nordsborg R, Lillelund, KG, Jakobsen, J, Tionneland, A, Overvad, K R$\mathrm{N}$, O. Exposure to Road Traffic and Railway Noise and Associations with Blood Pressure and Self-Reported Hypertension: A Cohort Study. Environtment Heal. 2011;Vol.10.

23. Primatesta, P, Falaschetti, E, Gupta, S, Mamot, MG, Poulter N. Association Between Smoking and Blood Pressure: Evidence from The Health Survey for England. Sci Contrib. 2001;

24. Anggara, FHD \& Prayitno N. FaktorFaktor yang Berhubungan dengan Tekanan Darah di Puskesmas Telaga Murni Cikarang Barat Tahun 2012. J Ilm Kesehat. 2013;Vol.5.

25. Ambrose, John A \& Barua RS. The Patophysiology of Cigarette Smoking and Cardiovascular Disease. J Am Coll Cardiol. 2004; Vol.43,No.

26. Smith C. Particulate and Vapor Phase
Constituents of Cigarette Mainstream Smoke and Risk of Myocardial Infarction. Atherosclerosis. 2001; Vol.158.

27. Saryawati R. Faktor Risiko Kejadian Hipertensi Pada Pekerja Industri Tekstil. Universitas Diponegoro Semarang; 2008.

28. Hidayat S. Pengaruh Pemakaian Alat Pelindung Telinga (earplug) terhadap Perubahan Tekanan Darah Akibat Bising. Universitas Diponegoro Semarang; 2005.

29. Buchari. Kebisingan Industri dan Hearing Conservation Program. Respository Univ Sumatra Utara. 2007;

30. Setyaningrum, I, Widjasena, B S. Analisa Pengendalian Kebisingan pada Penggerindaan di Area Fabrikasi perusahaan Pertambangan. J Kesehat Masy. 2014;Vol.2. 